\title{
DISTRIBUSI UKURAN DAN POLA MUSIM PENANGKAPAN RAJUNGAN (Portunus pelagicus) DI PERAIRAN KABUPATEN PANGKEP
}

\author{
Size Distribution and Fishing Season Patterns of Swimming Crab (Portunus pelagicus) \\ in The Waters of Pangkep District - South Sulawesi
}

Oleh:

Ihsan $^{1}$

FPIK, UMI Makassar: ihsanpsp@yahoo.co.id

Diterima: 22 September 2017; Disetujui: 3 April 2018

\begin{abstract}
The swimming crab potential is a resource that has high economic value. Therefore the utilization needs to be done continuously and to achieve this is by conducting an important research focussed on the size and the fishing season pattern of the swimming crab by studying the pattern of the catching season, it is expected to improve the efficiency and effectiveness of the catching time. The objective of this research is to 1. Map the distribution of the frequency and size of crab and 2. Determine the pattern of fishing season in Pangkep waters. The research is conducted from March to November 2016. It is located in Pangkep waters regency, South Sulawesi Province. The data is collected through survey method consisted of primary and secondary data. The data were analyzed using frequency distribution analysis approach and time series analysis technique toward catch $(\mathrm{kg})$ of fishing effort. The results obtained showed that the dominant female crab caught with a size $>10.0 \mathrm{~cm}$, as well as dominant male crabs caught with a size $>10 \mathrm{~cm}$. The fishing gear used is trap and gillnet. In addition the catching season is in May, June, July, September, October and November. The peak season of catching season takes place in June and September.
\end{abstract}

Keywords: Size distribution, Season pattern, swimming crab, at Pangkep District

\begin{abstract}
ABSTRAK
Potensi sumberdaya rajungan, merupakan komoditas sumberdaya yang memiliki nilai ekonomis penting, sehingga pemanfaatannya perlu dilakukan secara berkelanjutan. Untuk mencapai hal tersebut maka ukuran hasil tangkapan dan pola musim penangkapan rajungan menjadi penting untuk diteliti. Adanya informasi pola musim penangkapan, diharapkan dapat meningkatkan efesiensi dan efektifitas waktu penangkapan rajungan. Penelitian ini bertujuan untuk 1) memetakan distribusi frekuensi dan ukuran rajungan yang tertangkap, dan 2) menentukan pola musim hasil tangkapan rajungan di perairan Kabupaten Pangkep. Pelaksanaan penelitian dilaksanakan mulai bulan Maret sampai bulan November 2016, di perairan Kabupaten Pangkep Propinsi Sulawesi Selatan. Metode pengumpulan data dalam penelitian ini adalah dengan metode survei. Data yang dikumpulkan terdiri dari data hasil tangkapan rajungan per hari; panjang dan lebar $(\mathrm{cm})$ karapas dan berat $(\mathrm{gram} / \mathrm{kg})$ rajungan. Data dianalisis dengan menggunakan pendekatan analisis distribusi frekuensi dan teknik analisis deret waktu (time series) terhadap hasil tangkapan $(\mathrm{kg})$ persatuan upaya penangkapan. Hasil penelitian yang diperoleh menunjukkan bahwa distribusi frekuensi rajungan betina, tertangkap berukuran $<10,0 \mathrm{~cm}$, lebih sedikit dibandingkan yang tertangkap di atas ukuran $>10,0 \mathrm{~cm}$. Demikian juga rajungan jantan ukuran $<$ $10,0 \mathrm{~cm}$ jumlahnya lebih sedikit dan ukuran rajungan $>10,0 \mathrm{~cm}$ lebih dominan tertangkap. Alat tangkap yang digunakan adalah bubu lipat, dan gillnet rajungan. Pola musim penangkapan
\end{abstract}


rajungan di perairan Kabupaten Pangkep terjadi pada bulan Mei, Juni, Juli, September, Oktober dan November dan puncak musim berlangsung pada bulan Juni dan September.

Kata kunci: distribusi ukuran, pola musim, rajungan, Kabupaten Pangkep

\section{PENDAHULUAN}

Rajungan merupakan jenis crustacea dan termasuk dalam komoditi perikanan laut yang bernilai ekonomis penting yang memiliki pasaran ekspor yang tinggi. Saat ini rajungan banyak diburu oleh nelayan dan umumnya ditemukan di perairan pantai, dan laut dalam. Untuk memenuhi kebutuhan pasar masih mengandalkan penangkapan dari laut, dan untuk budidaya rajungan masih dalam proses penelitian, untuk menentukan metode budidaya yang terbaik. Setiap tahun permintaan rajungan mengalami peningkatan, dan dikhawatirkan menyebabkan terjadi kelebihan tangkap rajungan pada masa yang akan datang.

Ihsan et al. (2014) mengatakan bahwa potensi sumberdaya rajungan tidak tersebar merata di seluruh perairan Kabupaten Pangkep. Hal ini dikarenakan perbedaan kondisi lingkungan perairan. Pada umumnya rajungan menyebar merata di seluruh kecamatan pesisir pantai dan kecamatan kepulauan terdekat di Kabupaten Pangkep.

Rajungan hidup di perairan dangkal mulai kedalaman 2-70 m dengan substrat berpa-sir sampai berpasir berlumpur. Rajungan ba-nyak berada di area perairan sekitar mang-rove, padang lamun dan terumbu karang. Pada fase zoea-crab banyak ditemukan di daerah perairan pantai, termasuk rajungan dewasa sampai yang mencapai umur 1 tahun (Adam et al. 2006; Sunarto 2012). Sumberdaya rajungan banyak ditangkap oleh nelayan dengan menggunakan gillnet dasar, mini trawl, dan bubu lipat. Ditangkap dalam jumlah yang sangat banyak untuk dijual dalam bentuk segar dan beku di pasaran lokal dan ekspor.

Tingkah laku rajungan dipengaruhi oleh beberapa faktor alami diantaranya adalah perkembangan hidup, kebiasaan makan, pengaruh siklus bulan, reproduksi dan pengaruh parameter oseanografi diantaranya pasang surut. Rajungan termasuk hewan perenang aktif, karena selalu berenang aktif dari dasar hingga permukaan air. Untuk menangkap rajungan digunakan berbagai jenis alat tangkap diantaranya gillnet dasar, bubu lipat dan mini trawl. Alat tangkap gillnet dan bubu lipat dioperasikan secara pasif di dasar perairan dan mini trawl dioperasikan secara aktif oleh nelayan dengan cara ditarik (dihela) dengan kapal pada kecepatan tertentu didasar perairan. Permasalahan yang dihadapi selama ini adalah Permen KP No 1 tahun 2015 dimana ukuran rajungan yang boleh ditangkap adalah ukuran $>10 \mathrm{~cm}$, sedangkan nelayan tidak membatasi diri terhadap ukuran hasil tangkapan yang boleh ditangkap. Demikian juga musim puncak penangkapan belum dikenal dengan baik oleh nelayan. Nelayan hanya mengetahui bahwa musim penangkapan rajungan tetap ada sepanjang tahun. Penelitian ini bertujuan: 1) memetakan distribusi frekuensi, ukuran rajungan yang tertangkap, dan 2) menentukan pola musim hasil tangkapan nelayan di perairan Kabupaten Pangkep. Hasil penelitian ini diharapkan memberikan manfaat kepada nelayan dan para pengambil kebijakan terkait informasi musim penangkapan rajungan dan ukuran rajungan yang tertangkap.

\section{METODE PENELITIAN}

Penelitian ini dilaksanakan pada bulan Maret-November 2016 dengan lokasi penelitian di perairan Kabupaten Pangkep Propinsi Sulawesi Selatan (Gambar 1). Penelitian ini menggunakan alat dan bahan penelitian, sebagaimana disajikan pada Tabel 1.

Metode pengumpulan data yang digunakan dalam penelitian ini adalah dengan metode survei (pengamatan langsung dilapangan) dengan cara mengikuti operasi penangkapan di fishing ground rajungan yang ditetapkan nelayan. Pengoperasian alat dilakukan selama penelitian berlangsung. Pemberangkatan dari fishing base ke lokasi penangkapan dilakukan pada pukul 05.00 atau 07.00 WIB. Pemasangan dan penarikan jaring dilakukan 1-2 kali per-trip dengan lama perendaman alat untuk satu kali penurunan sampai penarikan jaring berkisar 12 jam. Setelah masa perendaman jaring selesai maka dilakukan hauling diawali dengan pengangkatan pelampung tanda pertama, kemudian diikuti dengan penarikan badan jaring secara keseluruhan sampai pada pengangkatan pelampung terakhir atau pelampung tanda kedua. Pada saat pengangkatan jaring juga dilakukan pengumpulan hasil tangkapan. Setelah keseluruhan jaring dan hasil tangkapan diangkat kemudian perahu meninggalkan fishing ground menuju fishing base. Sedangkan pengoperasian alat bubu lipat dilakukan setelah tiba di fishing base pada pukul 05.00 atau 07.00 WIB. Pemasangan dan 


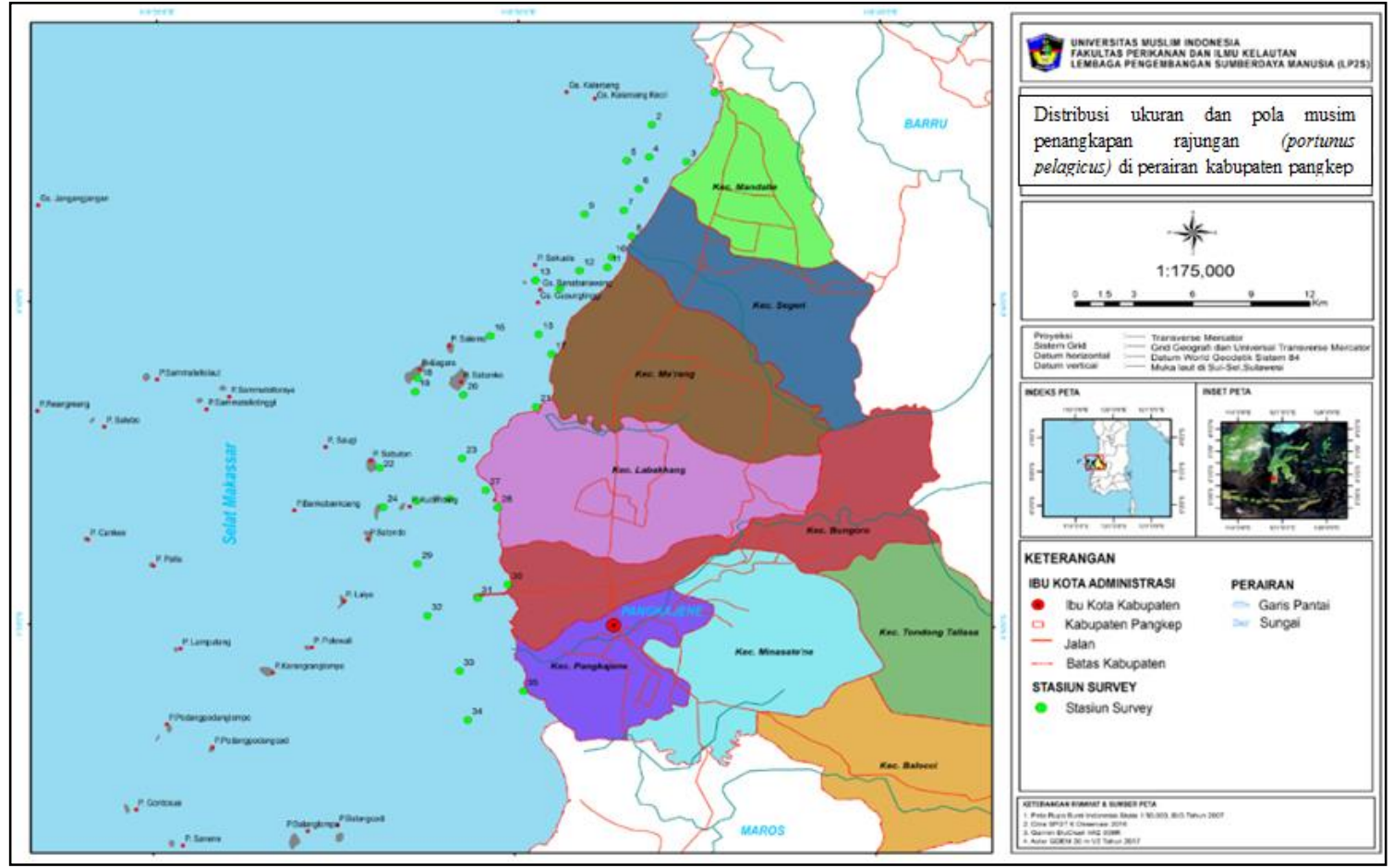

Gambar 1 Peta Lokasi Penelitian di perairan Kabupaten Pangkep

Tabel 1 Alat dan bahan yang digunakan dalam penelitian ini.

\begin{tabular}{l}
$\begin{array}{l}\text { Alat-alat dan } \\
\text { bahan }\end{array}$ Satuan $\quad$ Kegunaan \\
\hline
\end{tabular}

a. Alat-alat:

- Gillnet, bubu lipat

- Mistar

- Alat tulis

- Timbangan elektrik

b. Bahan:

- Rajungan

- Kuisioner unit

$\mathrm{cm}$

unit

gram

eksemplar
- alat penangkapan rajungan

- mengukur panjang dan lebar rajungan $(\mathrm{cm})$

- untuk menulis data yang dikumpulkan dalam penelitian

- menentukan berat rajungan penarikan bubu lipat dilakukan 1-2 kali per-trip dengan lama perendaman alat untuk satu kali penurunan sampai penarikan bubu lipat berkisar 12 jam. Setelah masa perendaman bubu lipat selesai maka dilakukan hauling diawali dengan pengangkatan pelampung tanda pertama, kemudian diikuti dengan penarikan bubu lipat satu persatu sampai pada pengangkatan pelampung tanda terakhir atau pelampung tanda kedua. Pada saat pengangkatan bubu lipat juga dilakukan pengumpulan hasil tangkapan. Setelah keseluruhan bubu lipat dan hasil tangkapan diangkat dan lokasi tersebut masih produktif maka bubu lipat tetap dioperasikan dilokasi ter- sebut, kemudian perahu meninggalkan fishing ground menuju fishing base.

Parameter utama yang diamati dalam penelitian ini adalah panjang, lebar $(\mathrm{cm})$ karapas dan berat $(\mathrm{gram} / \mathrm{kg})$ rajungan hasil tangkapan gillnet, dan bubu lipat. Pengukuran dilakukan selama 4 bulan (16 minggu), dan setiap minggu dilakukan pengukuran rajungan selama 3 kali secara acak. Jumlah rajungan yang diukur setiap pengukuran 30-40 ekor. Untuk mengum-pulkan data produksi hasil tangkapan rajungan dilakukan pencatatan pada setiap nelayan ko-lektor. Hasil tangkapan yang dicatat berupa produksi rajungan setiap harinya 
Saripuddin dan Ihsan (2016), menyatakan bahwa perbandingan ukuran $(\mathrm{Kg})$ hasil tangkapan rajungan yang tertangkap, digunakan pendekatan distribusi frekuensi, sehingga diketahui sebaran ukuran rajungan yang tertangkap. Langkah-langkah dalam penyusunan distribusi frekuensi antara lain:

a. mengurutkan data dari yang terkecil ke terbesar

b. menentukan range $(R)$ atau jangkauan dari data, dengan cara data terbesar dikurangi data terkecil (range/jangkauan).

c. menentukan banyaknya kelas ( $\mathrm{k}$ ) yakni $\mathrm{k}=$ $1+3,3 \log n$, dimana $k$ adalah banyaknya kelas dan $\mathrm{n}$ adalah banyaknya data.

d. menentukan panjang kelas yakni jangkauan/range $(R)$ dibagi banyaknya kelas $(k)$

e. menentukan batas bawah kelas pertama

f. menentukan frekuensi kelas dengan cara menghitung jumlah ukuran yang masuk lingkup kelas interval sesuai banyaknya data.

Analisis pola musim penangkapan rajungan ditentukan dengan menggunakan teknik analisis deret waktu (time series) terhadap hasil tangkapan persatuan upaya penangkapan bulanan rajungan selama enam tahun terakhir. Pendugaan musim penangkapan dilakukan dengan menganalisis data time series rajungan selama tahun 2009 s/d tahun 2014 yang didaratkan di perairan Kecamatan Sigeri, Kabupaten Pangkep. Pola musim penangkapan ikan dianalisis dengan menggunakan pendekatan metode rata-rata bergerak (moving average). Langkah penghitungannya menurut Dajan (1983) dan dikembangkan formulanya oleh Wiyono (2001) adalah sebagai berikut:

(1) menghitung data deret waktu CPUE kuartal pertama tahun 2009 hingga tahun 2014 yaitu:

$Y i=$ CPUEi

dimana $\mathrm{i}=1,2,3, \ldots \mathrm{n}$ dan $Y i=$ CPUE ke-i

(2) Menyusun rata-rata bergerak CPUE kuartalan $(R G)$.

$\mathrm{RGi}=\sum_{i=i-2}^{i+1}$ CPUE.

dimana $\mathrm{i}=4,5,6 \ldots ., \mathrm{n}-1$

(3) Menyusun rata-rata bergerak CPUE terpusat (RGP).

$R G P i=\frac{1}{2}=\sum_{i=1}^{i+1}$ CPUE

dimana $i=4,5,6 \ldots ., n-1$

(4) Menghitung rasio rata-rata untuk tiap kuartal $(R b)$.

$R b_{i}=\frac{C P U E_{i}}{R G P i}$ dimana $\mathrm{i}=$ kuartal I, II, III, .....VI

(5) Menyusun nilai rasio rata-rata dalam matrik berukuran $\mathrm{j} x \mathrm{I}$ yang disusun untuk setiap kuartal dimulai kuartal VI-I, kemudian menghitung rata-rata atau variasi musim dan selanjutnya menghitung indeks musim penangkapan.

(i) Rasio rata-rata untuk kuartal ke-I (RRB)

$$
\mathrm{RRBi}=\frac{1}{n} \sum_{j=1}^{n} R B i j
$$

(ii) Jumlah rasio rata-rata kuartalan (JRRB) $\mathrm{JRRB}=\sum_{i=1}^{n} R R B i$

Dimana $i=I$, II, III.......VI

(iii) Indeks musim penangkapan

Karena jumlah rasio rata-rata kuartalan (JRRB) tidak selalu sama dengan 400 maka nilai rasio rata-rata kuartalan harus dikoreksi dengan suatu factor koreksi (FK)

$\mathrm{FK}=\frac{400}{\text { JRRB }}$

Selanjutnya indeks musim penangkapan (IMP) dihitung dengan persamaan:

$\mathrm{IMPi}=\mathrm{RRBi} \times \mathrm{FK}$

Dimana i $=\mathrm{I}, \mathrm{II}, \mathrm{III}, \ldots . . \mathrm{VI}$

\section{HASIL}

Hasil perhitungan distribusi frekuensi rajungan secara umum menunjukkan bahwa dengan alat tangkap bubu lipat dan gillnet baik betina maupun jantan, ukuran rajungan $<10,0$ $\mathrm{cm}$ lebih sedikit tertangkap jika dibandingkan dengan ukuran diatas $>10,0 \mathrm{~cm}$.

Hasil analisis distribusi frekuensi untuk rajungan betina, tertangkap ukuran $<10,0 \mathrm{~cm}$ sebanyak 64 ekor, sedangkan diatas ukuran > $10,0 \mathrm{~cm}$ sebanyak 770 ekor dari jumlah sampel yang diambil sebanyak 1526 ekor. Selengkapnya histogram distribusi frekuensi rajungan betina disajikan pada Gambar 2.

Hasil analisis distribusi frekuensi untuk rajungan jantan dari 1526 ekor yang disampling terdapat rajungan jantan ukuran $<10,0 \mathrm{~cm}$ sebanyak 105 ekor dan ukuran rajungan jantan $>10,0 \mathrm{~cm}$ sebanyak 587 ekor. Selengkapnya histogram distribusi frekuensi rajungan jantan disajikan pada Gambar 3.

Hasil analisis distribusi frekuensi untuk rajungan betina dan jantan dari 1526 ekor yang disampling terdapat rajungan jantan ukuran < $10,0 \mathrm{~cm}$ sebanyak 169 ekor dan ukuran rajungan jantan $>10,0 \mathrm{~cm}$ sebanyak 157 ekor. 


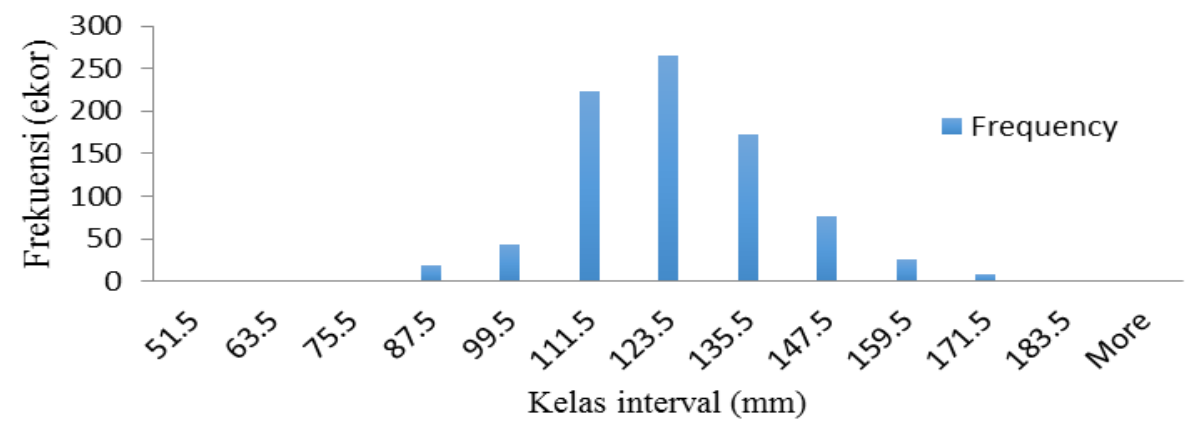

Gambar 2 Distribusi frekuensi ukuran $(\mathrm{mm})$ rajungan betina yang tertangkap di perairan Kabupaten Pangkep

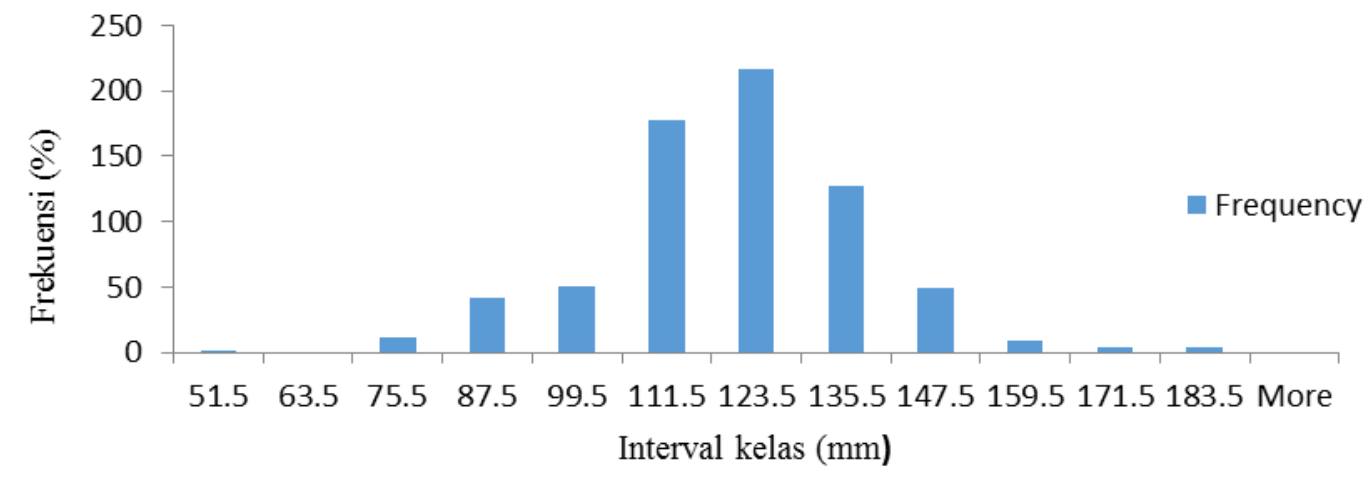

Gambar 3 Distribusi frekuensi ukuran $(\mathrm{mm})$ rajungan jantan yang tertangkap di perairan Kabupaten Pangkep

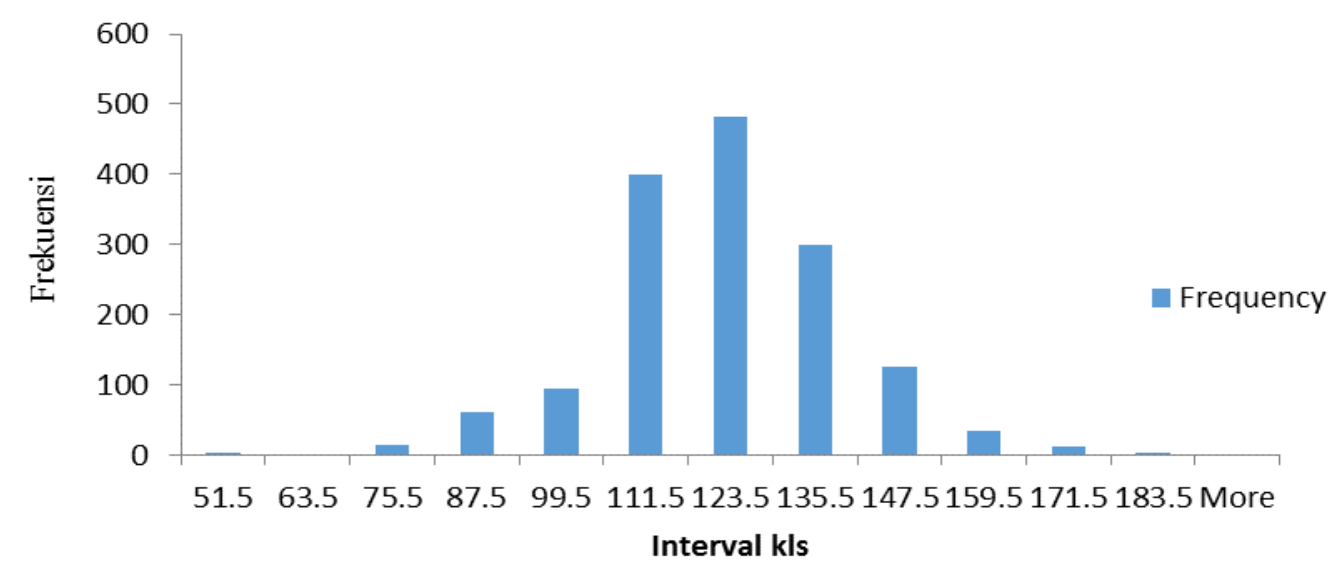

Gambar 4 Distribusi frekuensi ukuran $(\mathrm{mm})$ gabungan rajungan betina dan jantan yang tertangkap di perairan Kabupaten Pangkep

Masih adanya ukuran rajungan yang tertangkap $<10 \mathrm{~cm}$, merupakan suatu hal yang sulit dihindari oleh karena proses tertangkapnya rajungan lebih dominan terbelit-belit pada jaring. Selengkapnya histogram distribusi frekuensi rajungan jantan disajikan pada Gambar 4.

Hasil analisis rasio total rata-rata untuk bulanan (RRBi) adalah 12,74 dan faktor kondisi (FK) 94,21. Secara lengkap perbandingan antara RRBi dengan faktor kondisi berdasarkan data produksi rajungan selama lima tahun yakni tahun 2009 s/d tahun 2014 disajikan pada Tabel 2.

Musim dan Indeks Musim Penangkapan (\%) dari hasil perbandingan rasio rata-rata untuk bulanan dengan faktor kondisi (FK) berdasarkan data produksi rajungan selama lima tahun yakni tahun 2009-2014 diperoleh puncak musim penangkapan rajungan yakni pada bulan Juni, sebagaimana disajikan pada Gambar 5. 
Tabel 2 Hasil analisis rata-rata untuk bulanan (RRBi) dan indek musim penangkapan (IMP) rajungan

\begin{tabular}{lrr}
\hline \multicolumn{1}{c}{ Musim } & RRBI & IMP (RRBi/FK) \\
\hline Januari & 0,78 & 73,6 \\
Februari & 0,65 & 61,4 \\
Maret & 0,64 & 59,9 \\
April & 0,70 & 65,8 \\
Mei & 1,34 & 126,5 \\
Juni & 1,62 & 152,5 \\
Juli & 1,13 & 106,4 \\
Agustus & 0,94 & 88,8 \\
September & 1,50 & 141,4 \\
Oktober & 1,37 & 129,4 \\
\hline Nopember & 1,21 & 113,9 \\
Desember & 0,86 & 80,5 \\
\hline Total (rata-rata) & 12,74 & \\
\hline Faktor koreksi (FK) & 94,21 & \\
\hline Sumber: diolah berdasarkan hasil pengumpulan data di Lapangan &
\end{tabular}

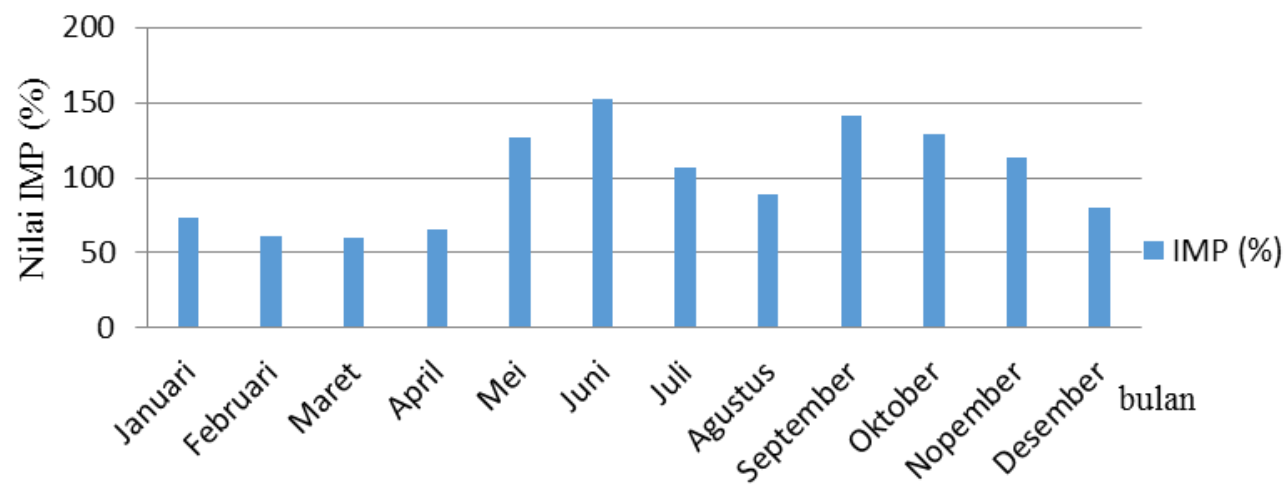

Gambar 5 Musim dan Indeks Musim Penangkapan (\%) dari hasil perbandingan rasio rata-rata untuk bulanan dengan faktor kondisi

\section{PEMBAHASAN}

Hasil analisis pemetaan distribusi frekuensi rajungan betina, ukuran $<100 \mathrm{~mm}$ tertangkap 64 ekor sedangkan diatas ukuran > $100 \mathrm{~mm}$ tertangkap 770 ekor dari 1526 ekor yang telah diukur. Hubungan kelas interval terhadap distribusi frekuensi rajungan didominasi pada kelas interval 112-123 mm dengan frekuensi 265 ekor atau $31,77 \%$ dari seluruh rajungan betina, disusul kelas interval 100-111 mm dengan frekuensi 223 ekor atau 26,74\% dari seluruh rajungan betina dan kelas interval 124$135 \mathrm{~mm}$ dengan frekuensi 172 ekor atau $20,62 \%$ dari seluruh rajungan betina. Rajungan yang tertangkap pada ukuran $<100 \mathrm{~mm}$ hanya sekitar $7,67 \%$ dari rajungan betina. Selain 3 ukuran kelas interval yang mendominasi hasil tangkapan rajungan betina juga terdapat kelas interval 136-171 $\mathrm{mm}$ dengan persentase hasil tangkapan sebesar $13,19 \%$. Hal ini tidak jauh berbeda dengan hasil kajian Kembaren dan Surahman (2018) di Kepulauan Aru, dimana rajungan betina berkisar antara 92,5-181 mm dengan lebar karapas rata-rata $141 \mathrm{~mm}( \pm 16)$.
Mawaluddin et al. (2016), di perairan Lakara Konawe Selatan Sulawesi Tenggara komposisi ukuran lebar karapas rajungan betina dewasa berdasarkan siklus hidup fase bulan gelap $110,00-140,25 \mathrm{~mm}$ dengan rata-rata 119,71 $\mathrm{mm}$ dan fase bulan terang 110,64-120,40 mm dengan rata-rata $114,84 \mathrm{~mm}$.

Untuk rajungan jantan dari 1526 ekor yang disampling, rajungan jantan ukuran $<100$ $\mathrm{mm}$ sebanyak 105 ekor dan ukuran $>100 \mathrm{~mm}$ sebanyak 587 ekor. Hubungan kelas interval distribusi frekuensi rajungan didominasi kelas interval $112-123 \mathrm{~mm}$ sebanyak 217 ekor atau $31,36 \%$, kelas interval $100-111 \mathrm{~mm}$ sebanyak 177 ekor atau $25,58 \%$ dan kelas interval 124 $135 \mathrm{~mm}$ sebanyak 127 ekor atau $18,35 \%$ dari seluruh hasil tangkapan rajungan jantan. Rajungan jantan yang tertangkap pada ukuran $<10,0 \mathrm{~cm}$ hanya sekitar $15,17 \%$ dari seluruh hasil tangkapan rajungan jantan. Selain 3 ukuran kelas interval yang mendominasi hasil tangkapan rajungan jantan juga terdapat kelas interval $136-171 \mathrm{~mm}$ dengan persentase hasil tangkapan $9,54 \%$. Kembaren dan Surahman 
(2018) menunjukkan hasil kajian yang sama di Kepulauan Aru, dimana sebaran ukuran lebar karapas $(\mathrm{CW})$ rajungan jantan yang tertangkap selama penelitian berkisar antara 92,5-183 mm dengan lebar karapas rata-rata $136 \mathrm{~mm}$ $( \pm 15,5)$. Mawaluddin et al. (2016) di perairan Lakara Konawe Selatan Sulawesi Tenggara komposisi ukuran lebar rajungan jantan dewasa berdasarkan siklus hidup pada fase bulan gelap $100,17-150,20 \mathrm{~mm}$ dengan rata-rata 114,33 $\mathrm{mm}$ dan fase bulan terang 100,96-140,20 mm dengan rata-rata 120,62.

Berdasarkan uraian tersebut hasil penelitian yang dilakukan oleh Harris (2003); Ihsan et al. (2015), rajungan dengan ukuran lebar karapas > $130 \mathrm{~mm}$ di pasar Australia dibayar dengan harga premium. Borg dan Campbell (2003) mengusulkan untuk perikanan komersial di Geographe Bay Australia ukuran layak tangkap untuk rajungan sebesar $128 \mathrm{~mm}$ lebar karapas atau $64 \mathrm{~mm}$ panjang karapas sedangkan untuk perikanan rekreasi (Recreational Fishing) ditetapkan ukuran legal sebesar 127 $\mathrm{mm}$. Pemberlakuan regulasi ukuran minimum yang legal akan menjaga kelestarian sumberdaya rajungan dan pasokan bahan baku industri pengalengan rajungan yang masih mengandalkan hasil tangkapan dari laut. Ihsan et al. (2014) mengatakan bahwa lebar ukuran karapas rajungan yang dominan tertangkap oleh nelayan masih dalam kriteria normal dimana rajungan betina dengan jantan untuk ukuran rajungan < $10 \mathrm{~cm}$ jumlahnya masih lebih kecil jika dibandingkan ukuran rajungan $>10 \mathrm{~cm}$.

Zairion et al. (2015), di perairan Lampung Timur, rajungan jantan berkisar antara 71,27$181,17 \mathrm{~mm}$ dengan rata-rata 119,88 \pm 19,86 $\mathrm{mm}$. Hosseini et al. (2012) bahwa lebar karapas rajungan di pantai Teluk Persia Iran, rajungan jantan berkisar antara 60-150 mm dan betina antara 50-145 $\mathrm{mm}$.

Hasil penelitian rajungan diperairan lainnya seperti di perairan Pati ditemukan rata-rata ukuran tertangkap dan matang gonad rajungan masing-masing sebesar $108 \mathrm{~mm}$ dan $107 \mathrm{~mm}$ (Ernawati et al. 2014), di perairan Timur Lampung rata-rata tertangkap pada lebar karapas 95,5 $\mathrm{mm}$ (jantan) dan 99,4 $\mathrm{mm}$ (betina) dan matang gonad pada lebar karapas $103 \mathrm{~mm}$ (Zairion 2015; Zairion et al. 2015), di perairan Belitung rata-rata ukuran tertangkap pada lebar karapas $93 \mathrm{~mm}$ dan mencapai ukuran matang gonad pada lebar karapas 118,98 mm.

Hubungan kelas interval terhadap distribusi frekuensi rajungan jantan dan betina tertangkap didominasi pada kelas interval 112-123 $\mathrm{mm}$ dengan frekuensi 482 ekor atau 31,59\% dari seluruh hasil tangkapan rajungan jantan dan betina. Disusul kemudian kelas interval $100-111 \mathrm{~mm}$ dengan frekuensi 400 ekor atau $26,21 \%$ dari seluruh hasil tangkapan rajungan jantan dan betina dan kelas interval 124-135 mm dengan frekuensi 299 ekor atau 19,59\% dari seluruh hasil tangkapan rajungan jantan dan betina.

Rajungan jantan dan betina yang tertangkap pada ukuran < 10,0 cm hanya sekitar $11,07 \%$ dari seluruh hasil tangkapan rajungan jantan dan betina. Selain 3 ukuran kelas interval yang mendominasi hasil tangkapan rajungan jantan dan betina juga terdapat kelas interval lebih besar ukurannya yakni 136-171 $\mathrm{mm}$ dengan persentase hasil tangkapan sebesar 19,76\%. Dengan demikian secara keseluruhan dari 1526 ekor rajungan yang disampling didominasi ukur-an lebih panjang 10 $\mathrm{cm}$.

Ihsan et al. (2014) bahwa nelayan menangkap rajungan yang lebih dekat dari perairan pantai didominasi rajungan dewasa tapi ukurannya masih lebih kecil jika dibandingkan dengan rajungan yang tertangkap nelayan yang jauh dari pantai.

Peraturan Menteri Kelautan dan Perikanan No 1/PERMEN-KP/2015, Pasal 3 ayat (1) c. ukuran rajungan (Portunus pelagicus spp.) yang boleh ditangkap yakni lebar karapas $>10$ cm (di atas sepuluh sentimeter). Permen ini seharusnya tidak diberlakukan secara cepat tanpa ada kajian lengkap di seluruh wilayah perairan Indonesia, supaya teridentifikasi perairan mana yang mengalami over fishing atau over eksploitasi rajungan dengan isu dan permasalahan masing-masing daerah. Karakteristik nelayan dan potensi setiap daerah berbeda-beda, sangat sulit mengalihkan pekerjaan alternatif (pekerjaan baru) kepada nelayan, tanpa ada sosialisasi terlebih dahulu. Pada umumnya nelayan memiliki kemampuan terbatas untuk mengganti alat baru yang dapat menangkap rajungan yang berukuran lebih besar dari $100 \mathrm{~mm}$.

Menurut Syahrir (2011) bahwa nilai indeks musim penangkapan ikan dapat digunakan dalam penentuan waktu yang tepat dalam melakukan operasi penangkapan ikan. Kriteria yang dipakai dalam penentuan musim penangkapan ikan adalah jika nilai IMP sama dengan atau lebih dari $100 \%$ dikatakan sebagai musim penangkapan, sedangkan bukan musim penangkapan apabila nilai IMP kurang dari $100 \%$. Selanjutnya menurut Gaspersz (1996), bahwa jika total indeks musim selama setahun untuk bulanan adalah 1200 atau rata-rata sama dengan 100, sehingga total indeks musim untuk bulanan sebesar 400. Selanjutnya menurut Makridakis et al. (1983); Wiyono (2010) bahwa 
penentuan musim menggunakan kriteria diantaranya adalah jika indeks musim lebih dari 1 (lebih dari 100\%) atau di atas rata-rata, dan bukan musim jika indeks musim kurang dari 1 (kurang dari 100\%) dan apabila IM = 1 (100\%), nilai ini sama dengan harga rata-rata bulan-an sehingga dapat dikatakan dalam keadaan normal atau berimbang.

Berdasarkan kriteria IMP yang disampaikan oleh Syahrir (2011) dari data yang diperoleh setelah dianalisis diperoleh indek musim penangkapan rajungan berada pada kisaran terendah pada bulan Januari s/d Maret dan tertinggi antara bulan April s/d Desember. Hasil analisis menunjukan bahwa pola musim penangkapan rajungan di perairan Kabupaten Pangkep terjadi pada bulan Mei, Juni, Juli, September, Oktober, November dan musim puncak penangkapan rajungan berlangsung pada bulan Juni dan September. Jafar (2011) mengatakan bahwa produksi perikanan rajungan di Desa Mattiro Bombang (Pulau Salemo, Sabangko dan Sagara) Kabupaten Pangkep bulan Januari sebesar $828,3 \mathrm{~kg}$ dan menurun bulan Februari sebesar $713,8 \mathrm{~kg}$, bulan Maret pun mengalami penurunan sebesar $592,9 \mathrm{~kg}$,

Bulan April produksi rajungan $540,1 \mathrm{~kg}$, meningkat $1004 \mathrm{~kg}$ pada bulan Mei, disebabkan peralihan musim barat ke musim timur dan pada bulan Juni s/d bulan Juli produksi rajungan turun masing-masing $824,7 \mathrm{~kg}$, dan 446,5 kg. Selanjutnya pada bulan Agustus s/d Desember meningkat masing-masing sebesar $503,8 \mathrm{~kg}, 532,5 \mathrm{~kg}, 605,1 \mathrm{~kg}, 647,1 \mathrm{~kg}$, dan $1022,5 \mathrm{~kg}$. Uraian tersebut sejalan hasil penelitian Wiyono dan Ihsan (2015) hasil tangkapan rajungan yang terbesar di Pangkajene Kepulauan terjadi pada musim kering/kemarau (Juni) selama bulan baru (bulan gelap). Selanjutnya perbandingan morfometrik gigi juga menyimpulkan hal yang serupa dimana lebar, panjang dan berat juga mencapai nilai tertinggi selama musim kemarau (Juni).

Almaida et al. (2015) di perairan Demak bahwa produksi atau hasil tangkapan dipengaruhi oleh musim penangkapan rajungan dan jumlah trip penangkapan. Hasil tangkapan di perairan Betahwalang-Demak pada musim puncak penangkapan nelayan berkisar $20-30 \mathrm{~kg} /$ trip, bahkan dapat mencapai $40 \mathrm{~kg} / \mathrm{trip}$, musim biasa/sedang (April-Juli dan Oktober-November) berkisar 4-7 kg/trip, dan musim paceklik (Agustus dan September) sebanyak 1-4 kg/trip. Sebagai perbandingan, rata-rata hasil tangkapan nelayan rajungan Cirebon yang menggunakan jaring kejer pada bulan Desember-Maret (musim puncak) mencapai 40-60 kg/perahu/trip, sedangkan pada musim paceklik berkisar 3-10 kg/perahu/trip (Bahtiar et al. 2012).
Musim penangkapan rajungan turun pada Bulan Juli jika dibandingkan pada Bulan Juni walaupun demikian masih dalam kategori puncak musim penangkapan rajungan karena nilai indeksnya $>100 \%$. Selanjutnya pada Bulan Agustus nilai IMP $88,8<100 \%$. Hasil pengamatan dan wawancara yang dilakukan diperoleh informasi bahwa dipantai barat Selat Makassar terutama minggu terakhir bulan Juni-Agustus sedang mengalami musim pancaroba, yang diakibatkan oleh gelombang besar sehingga nelayan terkendala cuaca untuk melakukan penangkapan rajungan. Penyebab lainnya karena pada Bulan Agustus adalah puncak musim pemijahan rajungan, dimana rajungan betina dewasa yang sudah matang gonad berada pada dasar perairan yang lebih dalam dan jauh dari pantai. Insan et al. (2015) mengatakan bahwa rajungan dewasa betina setelah matang gonad sudah berangsur-angsur menjauhi dari perairan pantai bergerak menuju ke perairan yang lebih dalam (lepas pantai), untuk melakukan pemijahan. Lokasi pemijahan rajungan dan daerah penangkapan nelayan berbeda, memberikan keuntungan dan peluang yang besar pada rajungan untuk melakukan pemijahan. Selanjutnya memasuki bulan September indeks musim penangkapan rajungan meningkat kembali. $\mathrm{Pa}$ da bulan September merupakan akhir musim penangkapan rajungan setiap tahunnya. Penurunan IMP mulai bulan Oktober, sampai November. Pada bulan Desember, Januari, Februari, Maret, April dan Agustus tidak termasuk dalam indeks musim penangkapan rajungan.

Pada bulan Desember-Maret setiap tahun wilayah perairan Kabupaten Pangkep keadaan cuaca sangat jelek dimana angin barat bertiup sangat kencang yang menyebabkan gelombang besar sehingga jumlah trip penangkapan nelayan terbatas, akibatnya produksi rajungan menurun. Kurangnya intensitas penangkapan yang dilakukan oleh nelayan selama 4 bulan tersebut, jika dilihat dari sisi perlindungan (konservasi) merupakan hal yang sangat baik untuk mendukung, pertumbuhan dan perkembangan rajungan. Masa paceklik dari musim penangkapan rajungan, berakhir diperkirakan sekitar bulan April. Hasil wawancara dengan nelayan menunjukan bahwa setiap bulannya tetap ada operasi penangkapan, dengan memperhatikan kondisi perairan jika memungkinkan mereka melakukan operasi penangkapan rajungan. Jarak lokasi penangkapan dengan pangkalan pendaratan atau perkampungan nelayan tidak jauh, dengan lama waktu tempuh menuju daerah penangkapan dari pangkalan antara 0,5 - 1 jam.

Berdasarkan uraian diatas dan wawancara dengan nelayan memberikan suatu indikasi 
bahwa ukuran hasil tangkapan rajungan dipengaruhi oleh beberapa faktor antar lain: 1) musim penangkapan, 2) daerah penangkapan rajungan, 3). siklus hidup rajungan dan 4) skala usaha nelayan. Keempat indikasi ini hubungannya sangat kuat, siklus (daur) hidup rajungan antara pantai dan lepas pantai dimana pergerakan rajungan dari lepas pantai menuju pantai sebagai tempat pengasuhan, mencari makan dan pembesaran adalah komposisi rajungan yang berukuran kecil.

Pergerakan rajungan dari perairan pantai menuju perairan lepas pantai pada saat rajungan sudah mencapai tahap kematangan gonad. Ukurannya rajungan yang tertangkap di sekitar perairan pantai masih lebih kecil dibandingkan rajungan yang tertangkap di lepas pantai. Rajungan yang tertangkap pada awal musim penangkapan, ukurannya masih lebih kecil dibandingkan bulan berikutnya.

Nelayan yang menggunakan alat tangkap dengan armada sederhana maka lingkup penangkapannya hanya sekitar pantai ukuran hasil tangkapan lebih kecil dibandingkan nelayan yang memiliki armada penangkapan yang lebih besar maka daerah penangkapannya lebih jauh dari pantai, tentunya ukuran hasil tangkapannya lebih besar. Menurut Effendy et al. (2006), rajungan hidup di daerah estuaria kemudian bermigrasi ke perairan yang mempunyai salinitas yang lebih tinggi, saat telah dewasa, rajungan yang siap memasuki masa perkawinan akan bermigrasi di daerah pantai, setelah melakukan perkawinan, rajungan akan kembali ke laut untuk menetaskan telurnya. Ernawati et al. (2013), menunjukkan bahwa kedalaman $>20$ meter, ukuran lebar karapaks rajungan betina yang tertangkap berukuran rata-rata $189 \mathrm{~mm}$. Ernawati et al. (2014) di perairan sekitar wilayah Pati Jawa tengah pada bulan Desember diduga rajungan betina bermigrasi di luar area fishing ground. Rajungan betina melakukan migrasi ke perairan yang lebih dalam untuk melakukan pemijahan. Dijelaskan bahwa variasi nisbah kelamin disebabkan oleh migrasi rajungan betina yang telah matang gonad menuju ke daerah berpasir untuk menetaskan telurnya (Sumpton et al.1994). Perubahan tingkah laku dalam mencari makan rajungan betina selama periode musim pemijahan dapat mengurangi tertangkapnya rajungan betina oleh bubu (Xiao dan Kumar 2004).

Nugraheni et al. (2015) kelas ukuran rajungan berdasarkan lebar karapas yang tertangkap pada zona yang berbeda di perairan Kabupaten Pati, zona 1 memiliki lebar berkisar 60-138 mm (betina) dan 60-128 mm (jantan). Rajungan yang paling banyak tertangkap di zona 1 adalah rajungan dengan kisaran lebar karapas 60-120 mm baik betina maupun jantan yaitu rata-rata sebesar 114,9 $\pm 11,5 \mathrm{~mm}$ (betina) dan $109,8 \pm 13,9 \mathrm{~mm}$ (jantan). Adapun rajungan yang banyak tertangkap pada zona 2 memiliki lebar karapas berkisar antara 98-168 mm (betina) dan 92-158 mm (jantan).

\section{KESIMPULAN}

Hasil pembahasan yang dilakukan, selanjutnya diambil kesimpulan antara lain adalah pemetaan distribusi frekuensi, ukuran rajungan yang tertangkap, masing-masing rajungan betina dan jantan yang berukuran $<10,0 \mathrm{~cm}$ tertangkap lebih sedikit dibandingkan ukuran > $10,0 \mathrm{~cm}$ lebih dominan tertangkap. Hubungan kelas interval terhadap distribusi frekuensi rajungan didominasi pada kelas interval 112-123 $\mathrm{mm}$ dengan frekuensi $31,77 \%$ dari seluruh rajungan betina disampling. Hubungan kelas interval distribusi frekuensi rajungan didominasi kelas interval 112-123 mm sebanyak 31,36\% dari seluruh rajungan betina disampling. Pola musim penangkapan rajungan di perairan Kabupaten Pangkep terjadi pada bulan Mei, Juni, Juli, September, Oktober dan November dan puncak musim penangkapan berlangsung pada bulan Juni dan September di perairan Kabupaten Pangkep.

\section{SARAN}

Untuk menjaga keseimbangan potensi sumberdaya rajungan maka, disarankan menangkap rajungan pada ukuran diatas lebih besar $10 \mathrm{~cm}$, dengan alat tangkap bubu lipat dan gillnet rajungan. Waktu tertentu diluar pola musim penangkapan rajungan yang teridentifikasi, disarankan mengurangi intensitas penangkapan. Hal ini dimaksudkan untuk memberi kesempatan rajungan pada pemulihan.

\section{UCAPAN TERIMA KASIH}

Penulis mengucapkan terima kasih kepada Direktorat Riset dan Pengabdian kepada Masyarakat, Direktorat Jenderal Penguatan Riset dan Pengembangan Kementerian Riset, Teknologi, dan Pendidikan Tinggi yang telah membiayai penelitian ini melalui Kegiatan $\mathrm{Pe}$ nelitian Produk Terapan (Hibah Bersaing) dan para reviewer yang telah banyak memberikan masukan dan komentar untuk memperbaiki tulisan ini.

\section{DAFTAR PUSTAKA}

Almaida SD, Wijayanto, Ghofar A. 2015. Analisis Perbandingan Pendapatan Nelayan 
Bubu Desa Betahwalang dengan Pola Waktu Penangkapan Berbeda. Fisheries Resources Utilization Management and Technology Journal. 4(3): 1-9.

Adam, Jaya I, Sondita MF. 2006. Model Numerik Difusi Populasi Rajungan

(Portunus Pelagicus) di perairan Selat Makassar. Jurnal Ilmu-ilmu Perairan dan Perikanan Indonesia. 13(2): 83-88.

Bahtiar, Nuva R, Hidayat N K, Anggraeni D. 2012. Profitabilitas Pengelolaan Perikanan Tangkap Lestari: Aplikasi Kebijakan Pembatasan Ukuran Tangkap (Minimum Legal Size) Rajungan di Cirebon. Jurnal Ekonomi Lingkungan. 16(2): 78-87.

Borg J, Campbell C. 2003. Management of the Proposed Geographe Bay Blue Swimmer and Sand Crab Managed Fishery. A management Discussion Paper. Fisheries Management Paper No. 170.

Dajan A. 1983. Pengantar Metode Statistik. Jilid I. LP3ES. Jakarta.

Ernawati T, Boer M, Yonvitner. 2014. Biologi Populasi Rajungan (Portunus pelagicus Linnaeus) di Perairan Sekitar Wilayah Pati, Jawa Tengah. Bawal. 6(1): 31-40.

Effendy S, Sudirman, Bahri S, Nurcahyono E. Batubara H, Syaichudin. 2006. Petunjuk Teknis Pembenihan Rajungan Portunus Pelagicus Linnaeus. (Makalah). Departemen Kelautan dan Perikanan Direktorat Jenderal Perikanan Budidaya. Balai Budidaya Air Payau Takalar.

Gazperz JP. 1996. Analisis Sistem Terapan Berdasarkan Pendekatan Teknik Industri. Bandung: Tarsito.

Ihsan. 2016. Hubungan parameter Oseanografi terhadap Pendugaan Distribusi Spasial Siklus Hidup Rajungan di Perairan Kabupaten Pangkep. Seminar Nasional Perikanan dan Kelautan 2016. Dilaksanakan tanggal 17-11-2016. Prosiding. Fakultas Perikanan dan IImu Kelautan Universitas Padjajaran (UNPAD) Bandung. ISBN: 978-602-439-085-3.

Saripuddin, Ihsan. 2016. Distribusi Ukuran Rajungan yang Tertangkap dengan Bubu Lipat di Perairan Kelurahan Bira Kecamatan Tamalanrea Kota Makassar. Skripsi. Program Studi PSP FPIK UMI Makassar. Tidak dipublikasikan.

Sumpton WD, Potter MA, Smith GS. 1994. Reproduction and Growth of the Commercial Sand Crab, Portunus pelagicus
(L.) in Moreton Bay, Queensland. Asian Fisheries Science. 7: 103-113.

Hosseini M, Vazirizade A, Parsa Y, Mansori A. 2012. Sex Ratio, Size Distribution and Seasonal Abundance of Blue Swimming Crab, Portunus Pelagicus (Linnaeus, 1758) in Persian Gulf Coasts, Iran. J. World Applied Sciences.17(7): 919-925.

Ihsan, Wiyono ES, Wisudo SH, Haluan J. 2015. Alternatif Pengelolaan Perikanan Rajungan (Portunus pelagicus) di Perairan Kabupaten Pangkep Sulawesi Selatan. Jurnal Kebijakan Perikanan Indonesia (JPPI). Volume 7 Nomor 1 Mei 2015.

Ihsan, Wiyono ES, Wisudo SH, Haluan J. 2014. A Study of Biological Potential and Sustainability of Swimming Crab Population in the Waters of Pangkep Regency South Sulawesi Province. International Journal of Sciences: Basic and Applied Research (IJSBAR). 16(1): 351-363.

Insan, Wiyono ES, Wisudo SH, Haluan J. 2014. Pola Musim dan Daerah Penang-kapan Rajungan (Portunus Pelagicus) di Perairan Kabupaten Pangkep. (Season and Patterns of Catching Swimming Crab (Portunus pelagicus) in Pangkep Water Regency). Marine Fisheris. Jurnal Teknologi dan Manajemen Perikanan Laut. 5(2): 109-202.

Kembaren DD, Surahman A. 2018. Struktur Ukuran dan Biologi Populasi Rajungan (Portunus Pelagicus Linnaeus, 1758) di Perairan Kepulauan Aru. Jurnal Penelitian Perikanan Indonesia. Volume 24 Nomor 1 Maret 2018.

Kembaren DD, Ernawati T, Suprapto. 2012. Biologi dan Parameter Populasi Rajungan (Portunus Pelagicus) di Perairan Bone dan Sekitarnya. Jurnal Penelitian Perikanan Indonesia. J. Lit. Perikan. Ind. 18(4): 273-281.

Jafar L. 2011. Perikanan Rajungan di Desa Mattiro Bombang (Pulau Salemo, Sabangko dan Sagara) Kabupaten Pangkep. [Skripsi]. (tidak dipublikasi). Program Studi Manajemen Sumberdaya Perairan Jurusan Perikanan Fakultas IImu Kelautan dan Perikanan Universitas Hasanuddin. Makassar 2011.

Peraturan Menteri Kelautan dan Perikanan Republik Indonesia Nomor 1/PERMEN-KP/ 2015 Tentang Penangkapan Lobster ( $\mathrm{Pa}$ nulirus Spp.), Kepiting (Scylla Spp.), dan Rajungan (Portunus Pelagicus Spp.). 
Berita Negara Republik Indonesia Tahun 2015 Nomor 7.

Peraturan Menteri Kelautan dan Perikanan Republik Indonesia Nomor 2/PERMEN-KP/ 2015 Tentang Larangan Penggunaan Alat Penangkapan Ikan Pukat Hela (Trawls) dan Pukat Tarik (Seine Nets) di Wilayah Pengelolaan Perikanan Negara Republik Indonesia. Berita Negara Republik Indonesia Tahun 2015 Nomor 31.

Mawaluddin, Halili, Palupi RD. 2016. Komposisi Ukuran Kepiting Rajungan (Portunus Pelagicus) Berdasarkan Fase Bulan di Perairan Lakara, Konawe Selatan, Sulawesi Tenggara. Jurnal Manajemen Sumber Daya Perairan. 1(3): 299-310.

Marshall, Warburton SK, Paterson B., Mann D. 2004. Cannibalism in Juvenile BlueSwimmer Crabs Portunus Pelagicus (Linnaeus, 1766): Effects of Body Size, Moult Stage and Refuge Availability.

Nugraheni DI, Fahrudin A, Yonvitner. 2015. Variasi Ukuran Lebar Karapas dan Kelimpahan Rajungan (Portunus pelagicus Linnaeus) di Perairan Kabupaten Pati. Jurnal IImu dan Teknologi Kelautan Tropis. 7(2): 493-510.

Sunarto. 2012. Karakteristik Bioekologi Rajungan (Portunus Pelagicus) di Perairan Laut Kabupaten Brebes. Disertasi (tidak dipublikasikan). Sekolah Pascasarjana Institut Pertanian Bogor

Syahrir. 2011. Manajemen Penangkapan Ikan Pelagis di Perairan Teluk Apar Kabupaten Paser Provinsi Kalimantan Timur. Disertasi (tidak dipublikasikan). Sekolah Pascasarjana IPB. Bogor.
Wiyono ES, Ihsan. 2015. The Dynamic of Landing Blue Swimming Crab(Portunus Pelagicus) Catches in Pangkajenne Kepulauan, South Sulawesi, Indonesia. Aquaculture, Aquarium, Conservation \& Legislation International Journal of the Bioflux Society. (AACL BIOFLUX)2015, Volume 8, Issue 2. http://www.bioflux. com.ro/aacl.

Wiyono ES. 2010. Komposisi, Diversitas dan Produktivitas Sumberdaya Ikan Dasar di Perairan Pantai Cirebon, Jawa Barat. Jurnal IImu Kelautan UNDIP. www.ijms. undip.ac.id. Desember 2010. 15(4): 214220. ISSN 0853-7291. 214-220.

Wiyono ES. 2001. Optimasi Manajemen Perikanan Skala Kecil di Teluk Pelabuhanratu, Jawa Barat. [Tesis] Bogor. Institut Pertanian Bogor.

Zairion, Wardiatno Y, Fahrudin A. 2015. Sexual Maturity, Reproductive Pattern and Spawning Female Population of the Blue Swimming Crab, Portunus Pelagicus (Brachyura: Portunidae) in East Lampung Coastal Waters, Indonesia. Indian J. of Science and Technology. 8(7): 596-607.

Zulkarnain, Wisudo SH, Wahju RI. 2011. Teknologi Penangkapan dan Peluang Usaha Perikanan Tenggiri (Scomberomorus Commerson) di Kabupaten Belitung. Buletin PSP-IPB. XIX(2): 19-33.

Xiao Y, Kumar M. 2004. Sex Ratio and Probability of Sexualmaturity of Females at Size of the Blue Swimmer Crab, Portunus pelagicus Linnaeus off Southern Australia. Fisheries Research. 68: 271282. 